\title{
Structural and Functional Alterations of Skeletal Muscle Microvasculature in Dystrophin-Deficient $m d x$ Mice
}

\author{
Claire Latroche, ${ }^{* \dagger \ddagger \S}$ Béatrice Matot, ${ }^{\mathbb{T} \|}$ Aurea Martins-Bach, ${ }^{\mathbb{\top} \| * *}$ David Briand, ${ }^{*}$ Bénédicte Chazaud, ${ }^{\dagger \dagger \S}$ Claire Wary, ${ }^{\top \|}$ \\ Pierre G. Carlier, ${ }^{\mathbb{T} \|}$ Fabrice Chrétien, ${ }^{* \S \dagger \dagger}$ and Grégory Jouvion ${ }^{\star \S}$
}

\begin{abstract}
From the Infection and Epidemiology Department, * Human Histopathology and Animal Models, Institut Pasteur, Paris, France; The French Institute of Health and Medical Research (INSERM) U1016, ${ }^{\dagger}$ Institut Cochin, Paris, France; The French National Centre for Scientific Research (CNRS) Unité Mixte de Recherche 8104, ${ }^{\ddagger}$ Paris, France; the Paris Descartes University, ${ }^{\S}$ Pôle de Recherche, Enseignement Supérieur Sorbonne-Paris-Cité, Paris, France; the Nuclear Magnetic Resonance Laboratory, ${ }^{\top}$ Institut de Myologie, Paris, France; Commissariat à l'énergie atomique, Institut d'Imagerie Biomédicale, Molecular Imaging Research Center, Institut de Myologie," NMR Laboratory, Paris, France; the Laboratory of Muscle Proteins and Comparative Histology, ** Human Genome Research Center, Biosciences Institute, University of Sao Paulo, Sao Paulo, Brazil; and the Neuropathology Department, ${ }^{\dagger \dagger}$ Centre Hospitalier Sainte-Anne, Paris, France
\end{abstract}

Accepted for publication

May 5, 2015.

Address correspondence to Fabrice Chrétien, M.D., Ph.D., Human Histopathology and Animal Models, Institut Pasteur, 28 rue du Docteur Roux, 75015 Paris, France. E-mail: fabrice.chretien@pasteur.fr.

\begin{abstract}
Duchenne muscular dystrophy (DMD) is a progressive neuromuscular disease, caused by an absence of dystrophin, inevitably leading to death. Although muscle lesions are well characterized, blood vessel alterations that may have a major impact on muscle regeneration remain poorly understood. Our aim was to elucidate alterations of the vascular network organization, taking advantage of $\mathrm{Flk} 1^{\mathrm{GFP} /+}$ crossed with $m d x$ mice (model for human DMD where all blood vessels express green fluorescent protein) and functional repercussions using in vivo nuclear magnetic resonance, combining arterial spin-labeling imaging of perfusion, and ${ }^{31} \mathrm{P}$ spectroscopy of phosphocreatine kinetics. For the first time, our study focused on old (12-month-old) $m d x$ mice, displaying marked chronic muscle lesions, similar to the lesions observed in human DMD, in comparison to young-adult (3-month-old) $m d x$ mice displaying only mild muscle lesions with no fibrosis. By using an original approach combining a specific animal model, state-of-the-art histology/morphometry techniques, and functional nuclear magnetic resonance, we demonstrated that the microvascular system is almost normal in youngadult in contrast to old $m d x$ mice, displaying marked microvessel alterations, and the functional repercussions on muscle perfusion and bioenergetics after a hypoxic stress vary depending on stage of pathology. This original approach clarifies disease evolution and paves the way for setting up new diagnostic markers or therapeutic strategies. (Am J Pathol 2015, 185: 2482-2494; http://dx.doi.org/10.1016/j.ajpath.2015.05.009)
\end{abstract}

Duchenne muscular dystrophy (DMD) is the most frequent genetic neuromuscular disorder, affecting 1:3500 schoolaged boys worldwide. This X-linked muscle disease is characterized by progressive skeletal muscle weakness and cardiomyopathy, leading to premature death generally because of respiratory and/or cardiac failure. The cause of DMD is the absence of dystrophin, a key component of the dystrophin-associated protein complex involved in the linkage between myofiber cytoskeleton and extracellular matrix. When linkage is disrupted, muscle fibers develop normally but are more susceptible to damage because of mechanical stretch. Despite the presence of satellite cells (SCs; muscle stem cells) and successive regeneration attempts, myofibers undergo necrosis and are eventually replaced by connective and adipose tissues.

Muscle lesions in DMD have been widely investigated, with studies focusing principally on myofibers and/or SCs.

Supported by the Domaine d'Intérêt Majeur STEM-Pôle Stem Cells and Cell Medicine, Région Ile-de-France, Association Française Contre les Myopathies and Institut Pasteur institutional funding.

F.C. and G.J. contributed equally to this work as senior authors.

Disclosures: None declared.

Current address of B.C., Center of Genetic and Cellular and Molecular Physiology, Claude Bernard Lyon 1 University, Lyon, France and The French National Centre for Scientific Research (CNRS) Unité Mixte de Recherche 5534, Paris, France. 
Although skeletal muscle is one of the most vascularized tissues, endothelial cells are essential in the muscle regeneration process, and dystrophin is expressed in endothelial/ smooth muscle cells (SMCs); disease impact on blood vessels and effect of blood vessel alteration in disease expression remain poorly understood. In recent years, interest in the DMD vascular network has increased, with the primary focus on vasculature-related therapeutic strategies, ${ }^{2}$ such as methods to increase vasculature by modulating vascular endothelial growth factor (VEGF)/VEGF receptor pathways. ${ }^{3}$ These strategies were initially based on the observation of grouped necrosis in muscles of DMD patients (ie, simultaneous necrosis of contiguous myofibers), suggesting local failure in capillary blood supply and muscle ischemic necrosis, ${ }^{4}$ and membrane-associated nitric oxide synthase (NOS) deficiency in dystrophin-deficient muscle. ${ }^{5}$ The hypothesis of an ischemic process has been strongly discussed, because other studies could not detect any vascular bed abnormality in DMD, either morphologically using electron microscopy ${ }^{6}$ or physiologically by studying muscle blood flow. ${ }^{7-9}$ More recent studies in DMD patients confronted blood vessel alteration with tissue fibrosis, suggesting that endomysial fibrosis plays an essential role, causing an increase in capillary-to-myofiber distances, which impairs both muscle fiber mechanical function and gas exchanges. ${ }^{10}$ Moreover, increased distances between capillaries and myofibers could potentially impede their reciprocal stimulation by soluble factors secreted during muscle repair. ${ }^{11}$

Rare studies addressed the relevance of the muscle vascular network in dystrophinopathy pathophysiology in animal models, focusing on muscle vascular density and characterization of a possible hypoxic condition in dystrophic muscle. Part of these studies pointed to a decreased vascular density and an impaired angiogenesis in 6-weekold to 6-month-old $m d x$ mice, ${ }^{12-14}$ the dystrophin-deficient murine model of human DMD. However, contradictory results were also published in $m d x$ mice, showing a higher hind limb perfusion 1 week after femoral artery dissection and a significant increase in arteriole length density in 2-month-old animals. ${ }^{15}$ These discrepancies could be related, in part, to the effect of aging in disease progression; age appears to be an important parameter to consider when studying vascular changes. ${ }^{3}$ Thus, involvement of blood vessels in the pathogenesis of dystrophy is still not completely understood.

Herein, we investigated both structural organization and in vivo function of the vascular system in young-adult (3-month-old) $m d x$ mice, displaying only moderate subacute muscle lesions with no fibrosis, and old (12-monthold) $m d x$ mice, displaying marked muscle lesions with persistent inflammation and fibrosis, ${ }^{16}$ more relevant for the study of DMD pathophysiology in humans. We used complementary morphological approaches on the basis of genetically modified mice that allowed, for the first time, to reconstruct the 3D microvascular network in $m d x$ mouse.
These were compared with innovative histological techniques and dynamic and noninvasive multiparametric and functional nuclear magnetic resonance (NMR).

\section{Materials and Methods}

Mice

C57Bl/6J control mice were obtained from Charles River Laboratory (l'Arbresle, France); $m d x-4 \mathrm{Cv}$ with C57B1/6 background mice, model for human DMD, were kindly provided by Prof. Romain K. Gherardi (Henri Mondor Hospital, Créteil, France); Flk-1 ${ }^{\mathrm{GFP} /+}$ mice, in which green fluorescent protein (GFP) is targeted in VEGF receptor-2 gene locus, exhibiting a bright GFP signal in all endothelial cells, were kindly provided by Alexander Medvinsky (Institute for Stem Cell Research, University of Edinburgh, Edinburgh, UK); and $\mathrm{Flk}-1^{\mathrm{GFP} /+}:: m d x-4 \mathrm{Cv}$ mice were obtained by crossing Flk- ${ }^{\mathrm{GFP} /+}$ with $m d x-4 \mathrm{Cv}$ mice. Only male animals were used [ie, young adults ( 3 months old) or old (12 months old)].

Animals were housed in animal facilities of the Institut Pasteur (Paris, France), licensed by the French Ministry of Agriculture and complying with European Union regulations. Protocols were approved by the Institut Pasteur Animal Experimentation Ethics Committee (01332.01).

\section{Microvascular Network Organization in Three Dimensions}

Young-adult and old Flk- $1^{\mathrm{GFP} /+}$ and Flk- $1^{\mathrm{GFP} /+}:: m d x-4 \mathrm{Cv}$ mice were anesthetized with isoflurane inhalation (Forene; Abbott, Rungis, France) and sacrificed by cervical dislocation. Gastrocnemius muscles were removed, and imaging of the vascular network was performed in two conditions: thick cryosections or whole muscle. Gastrocnemius muscle was snap frozen in liquid nitrogen-cooled isopentane before dividing into cryosections (100 $\mu \mathrm{m}$ thick). Confocal acquisitions were performed using a spinning disk microscope (Leica, Wetzlar, Germany), and laser femtosecond was used: Chameleon Ultra (Coherent, Santa Clara, CA), $20 \times / 0.7$ and $40 \times / 0.75$ objectives, and a CoolSnap HQ2 camera (Photometrics, Tucson, AZ). Optical slices were taken every 0.5- or $0.3-\mu \mathrm{m}$ interval along the $z$ axis $(80 \mu \mathrm{m})$.

For whole muscle conditions, images of gastrocnemius blood vessels were obtained from the entire muscle using a multiphoton scanner resonant confocal Leica TCS-SP5 (Leica, Wetzlar, Germany) with $20 \times / 0.95$ objective. Optical slices were taken every $0.5 \mu \mathrm{m}$ along the $z$ axis.

\section{Histological/Immunohistochemical Analysis}

Gastrocnemius muscles were collected from mice after NMR experiments, snap frozen in liquid nitrogen-cooled isopentane, and kept at $-80^{\circ} \mathrm{C}$. Six different levels of sections $(7 \mu \mathrm{m}$ thick) were cut and stained with hematoxylin 
and eosin to describe histopathological modifications of muscle tissue, and Sirius red was used for visualization of collagen. For immunohistochemistry analyses, muscle cryosections were incubated with antibodies directed against endothelial cells (anti-CD31; Pharmingen, San Jose, CA), SCs (anti-Pax7; DHSB, Iowa city, IA), pericytes (anti-NG2; Millipore, Darmstadt, Germany), $\alpha$-SMA (Sigma, St. Louis, MO), and basal lamina (anti-laminin; Sigma). Primary antibodies were incubated overnight at $4^{\circ} \mathrm{C}$ and revealed by cy3- or tetramethylrhodamine-labeled secondary antibodies (Jackson ImmunoResearch Laboratories, Baltimore, PA).

\section{Morphometric Analysis}

Two-dimensional analysis was performed to evaluate distribution of muscle fiber diameter, percentage of centronucleated or perinucleated fibers, microvessel count, and distribution around each myofiber using ImageJ software version 1.49q (NIH, Bethesda, MD) and NIS-Element D software version 3.1 (Nikon, Tokyo, Japan). At least 200 fibers were considered for each muscle.

Three-dimensional analysis was performed to evaluate organization of the vascular network. For each muscle, 10 Z-stack image reconstructions were achieved on frozen sections (80 to $150 \mu \mathrm{m}$ thick). Analysis was performed using IMARIS Bitplane version 7.6 (ImarisBitplane, Zurich, Switzerland) software (quantification of vessel density, tortuosity, volume, anastomose count, diameter, and distance between microvessels).

\section{Quantitative Real-Time PCR}

We used real-time PCR to determine the level of angiogenesisrelated mRNA expression in young-adult and old $m d x$ mice. Total gastrocnemius muscle RNA was extracted using RNeasy Mini Kit (Qiagen, Venlo, the Netherlands). Total RNA (1 $\mu \mathrm{g})$ was reverse transcribed into first-strand cDNA using Superscript II Reverse Transcriptase (Life Technologies, Carlsbad, CA). Quantitative PCR was performed on a StepOne Plus RealTime PCR system (Applied Biosystems, Carlsbad, CA). Reaction mixtures had a final volume of $20 \mu \mathrm{L}$, consisting of 1 $\mu \mathrm{L}$ of cDNA, $10 \mu \mathrm{L}$ of SYBR Green Master (Roche, Bâle,
Switzerland), and $10 \mu \mathrm{mol} / \mathrm{L}$ of primers, listed in Table 1. After initial denaturation, amplification was performed at $95^{\circ} \mathrm{C}(10$ seconds), $60^{\circ} \mathrm{C}$ (5 seconds), and $7^{\circ} \mathrm{C}$ and $2^{\circ} \mathrm{C}$ (10 seconds) for 45 cycles. Calculation of relative expression was determined by the StepOnePlus software version 2.3 (Applied Biosystems, Paisley, UK), and fold change was normalized to $18 \mathrm{~S}$ rRNA housekeeping gene.

\section{NMR Analysis}

NMR experiments were performed on 3-month-old $m d x-4 \mathrm{Cv}$ $(n=6)$ and control C57B1/6J $(n=9)$ mice and on 12-monthold $m d x-4 \mathrm{Cv}(n=5)$ and control C57Bl/6J $(n=7)$ mice.

\section{Hyperemic Response Paradigm}

To highlight differences between normal and altered muscles, we classically applied a stress to increase the global need for perfusion. Ischemia-reperfusion stress was applied to the mouse left hind limb, which provokes maximal vasodilatation and limited resistance of arteries/arterioles ${ }^{17}$ just after tourniquet release.

In practice, anesthesia was induced with $4 \%$ isoflurane delivered in $1.5 \mathrm{~L} /$ minute air and maintained with $1.75 \%$ isoflurane. During experiments, a water heating pad ensured a constant temperature of $37^{\circ} \mathrm{C}$ and breathing was monitored. After a 24-minute NMR acquisition at rest (baseline), ischemia of the leg was induced by occlusion of the femoral artery by two surgical threads placed around the thigh and pulled tight by application of a weight. ${ }^{17}$ After 30 minutes of ischemia, the weight was instantly removed, inducing a hyperemic response that was monitored over the next 30 minutes. During the whole protocol, dynamic acquisitions of NMR scans of interleaved perfusion imaging and ${ }^{31} \mathrm{P}$-spectroscopy ( ${ }^{31} \mathrm{P}$-NMRS) were collected.

\section{Multiparametric Functional NMR Acquisitions}

In vivo NMR experiments were conducted in a 4-T Biospec system equipped with a 20-cm diameter 200-mT/m gradient insert (BrukerBioSpin MRI GmbH, Ettlingen, Germany). Mice were placed supine in a $6-\mathrm{cm}$ diameter, $12-\mathrm{cm}$ length volume transmitter ${ }^{1} \mathrm{H}$ coil for whole-body signal excitation. An actively decoupled 2-cm diameter surface ${ }^{1} \mathrm{H}$ coil,

Table 1 Oligonucleotide Primers Used for qPCR

\begin{tabular}{|c|c|c|}
\hline Primer & Forward sequence & Reverse sequence \\
\hline 18S rRNA & $5^{\prime}-$ CGGACAGGATTGACAGATTG- $3^{\prime}$ & $5^{\prime}-$ CAAATCGCTCCACCAACTAA- $3^{\prime}$ \\
\hline Flk1 & $5^{\prime}$-CAGTGGTACTGGCAGCTAGAAG- $3^{\prime}$ & $5^{\prime}$-ACAAGCATACGGGCTTGTTT-3' \\
\hline Flt1 & 5'-GGCCCGGGATATTTATAAGAAC-3' & $5^{\prime}$-CCATCCATTTTAGGGGAAGTC-3' \\
\hline VEGF & 5'-GGCGTGGTGGTGACATGGTT-3' & $5^{\prime}-\mathrm{ACCTCACCAAAGCCAGCACA-3^{ \prime }}$ \\
\hline CD31 & $5^{\prime}$-CGGTGTTCAGCGAGATCC-3' & $5^{\prime}$-ACTCGACAGGATGGAAATCAC- $3^{\prime}$ \\
\hline Ang1 & 5'-GACAGTAATACAACACCGGGAAGA-3' & 5'-СААААСССАТТTТАТАСТССТТССА-3' \\
\hline Ang2 & 5'-ACTACGACGACTCAGTGCAAAG-3' & 5'-TCTGGTTCTGCACCACATTC-3' \\
\hline Tie1 & $5^{\prime}$-AGGGCAGCTTCCAGAGTATG-3' & 5'-GGTTGGCCAGCAATGTTAAG-3' \\
\hline Tie2 & $5^{\prime}$-GGCTATAAGGATACGGACCATGAA-3' & $5^{\prime}-\mathrm{TCCCCTGTCCACGGTCATA-3^{ \prime }}$ \\
\hline nNOS & 5'-GGCGTTCGTGATTACTGTGA-3' & 5'-TСTTCСTCATGTCCAАATCCA-3' \\
\hline
\end{tabular}

nNOS, neuronal nitric oxide synthase; $9 P C R$, real-time quantitative PCR; VEGF, vascular endothelial growth factor. 
positioned below the left calf, was used for image signal reception. Muscle metabolites were probed by a $10-\mathrm{mm}$

${ }^{31} \mathrm{P}$ saddle-shaped coil placed around the left leg.

As described in detail elsewhere, ${ }^{17,18}$ arterial spin labeling NMR imaging and ${ }^{31} \mathrm{P}-\mathrm{NMRS}$ acquisitions were interleaved using the dedicated Bruker MultiScanControl software Paravision 3.0 (BrukerBioSpin $\mathrm{GmbH}$ ), to follow simultaneously and noninvasively muscle perfusion signal by SATurationInversion Recovery (time resolution, 10 seconds), and mitochondrial activity by dynamic ${ }^{31} \mathrm{P}-\mathrm{NMRS}$ (time resolution, 2.5 seconds). In brief, arterial spin labeling imaging is based on noninvasive alternate magnetic tagging of blood water spins to provide endogenous markers of muscle perfusion, measured in regions of interest drawn in the posterior compartment of the leg. Muscle bioenergetics and $\mathrm{pH}$ were assessed from ratios of energetic phosphates measurable by ${ }^{31} \mathrm{P}-\mathrm{NMRS}$ at rest, in vivo mitochondrial oxidative capacity was directly assessed from the rate of creatine rephosphorylation at the end of ischemia, and intramuscular $\mathrm{pH}$ was calculated from a chemical shift between phosphocreatine (PCr) and inorganic phosphate (Pi). A minimum of $50 \% \mathrm{PCr}$ depletion at the end of ischemia was necessary to reliably measure dynamics for PCr recovery, and examinations that did not reach this threshold were rejected.

\section{NMR Perfusion Analysis}

Images were acquired after positive or negative labeling alternately. To avoid large vessels, regions of interest were drawn in the posterior compartment of the leg. Muscle perfusion was calculated from the normalized difference between consecutive images, according to the following equation ${ }^{19}$ :

$$
f=-\lambda / T_{e v} \times \ln \left[\left(M^{+}-M^{-}\right) /\left(M^{+}+M^{-}\right) \times\left(1-\exp \left(r_{1} T_{e v}\right)\right)+1\right]
$$

where $r_{1}$ is the longitudinal relaxation rate for muscle (measured by saturation-recovery acquisition for each mouse at the end of a 30-minute hyperemic period), $M^{+}$and $M^{-}$are the signals of positive- and negative-labeled perfusion images, respectively, and $\lambda$ is the blood-tissue partition coefficient $(\lambda=0.9)$.

\section{${ }^{31}$ P-NMR Spectroscopy Analysis}

Successive ${ }^{31} \mathrm{P}$ free induction decays were acquired throughout rest, ischemia, and hyperemia. ${ }^{31} \mathrm{P}$-spectroscopy gives access to principal metabolites implicated in energetic metabolism, such as PCr, the three $\alpha, \beta$, and $\gamma$ ATPs, and Pi. The signal intensity of these resonances is directly proportional to their concentrations, which allows the quantitative following of these metabolite variations.

At ischemia and recovery, $\mathrm{PCr}$ recovery was fitted by a mono-exponential function with a least mean squares algorithm and $\mathrm{pH}$ was calculated from the chemical shift $\delta_{\mathrm{Pi}}$ between $\mathrm{PCr}$ and $\mathrm{Pi}$, according to the following formula ${ }^{20}$ :

$$
p H=6.75+\log \left[\left(3.27-\delta_{P i}\right) /\left(\delta_{P i}-5.69\right)\right]
$$

\section{Statistical Analysis}

Perfusion data were analyzed by repeated-measurements analysis of variance. Analyses were performed with NCSS2007 software (NCSS statistical software, Kaysville, UT). Group comparisons for perfusion parameters and phosphorus spectroscopy analysis were performed using the Mann-Whitney test.

Statistical analysis of histological data was performed with GraphPad-Prism software version 6.0f (GraphPad Software Inc., La Jolla, CA). Fiber diameter repartition was evaluated by a $\chi^{2}$ test, followed by a multi-t-test corrected for multiple comparisons using the Holm-Sidak method. The same multi-t-test was used to evaluate capillary count/ fiber repartition.

Statistical significance was taken at $P<0.05$. Numerical NMR and histological data are reported as means \pm SD.

\section{Results}

2Microvessels were defined as the small blood vessels located at the periphery of myofibers, in the endomysium, displaying a diameter of $<20 \mu \mathrm{m}$ and a wall sometimes containing one layer of $\alpha$-SMA-expressing cells, thus including capillaries, terminal arterioles, and terminal venules. ${ }^{21}$

\section{Young-Adult Flk1 $1^{\mathrm{GFP} /+}:$ :mdx Mice Display a Normal Microvascular Network Organization but a Mild Decrease in Terminal Arteriole Density}

Polyphasic subacute lesions, characterized by small inflammatory infiltrates and centrally nucleated fibers, were observed in gastrocnemius muscle (Figure 1, A and B). Surprisingly, these lesions had no impact on blood microvascular network organization. In both $\mathrm{Flk} 1^{\mathrm{GFP} /+}$ and Flk $1^{\mathrm{GFP} /+}:: m d x$ mice, the vascular network was well organized, with straight microvessels located along myofibers, parallel to each other, with few anastomoses oriented perpendicularly to myofibers (Figure 1, C-F). Microvessel diameter, measured using diameter of endothelial cell fluorescence, was similar in both groups (13 to $14 \mu \mathrm{m}$ thick), as well as anastomose count (1200 to 1650 anastomoses $/ \mathrm{mm}^{3}$ ) (Figure 1, G and $\mathrm{H}$ ).

Immunofluorescence analyses did not detect any significant difference between young-adult wild-type (wt) and $m d x$ mice (Figure 2, A-E). Both muscles displayed the same myofiber cross-section diameter, fiber size distribution, and microvessel density, quantified by microvessel count per fiber. No macrovascular modification was detected either (data not shown). To characterize further the microvascular network and identify terminal arterioles, we performed an immunohistochemistry against $\alpha$-SMA, highlighting perivascular SMCs. We quantified a $26 \%$ loss of $\alpha$-SMA expression in $m d x$ mice, suggesting a decrease in terminal 

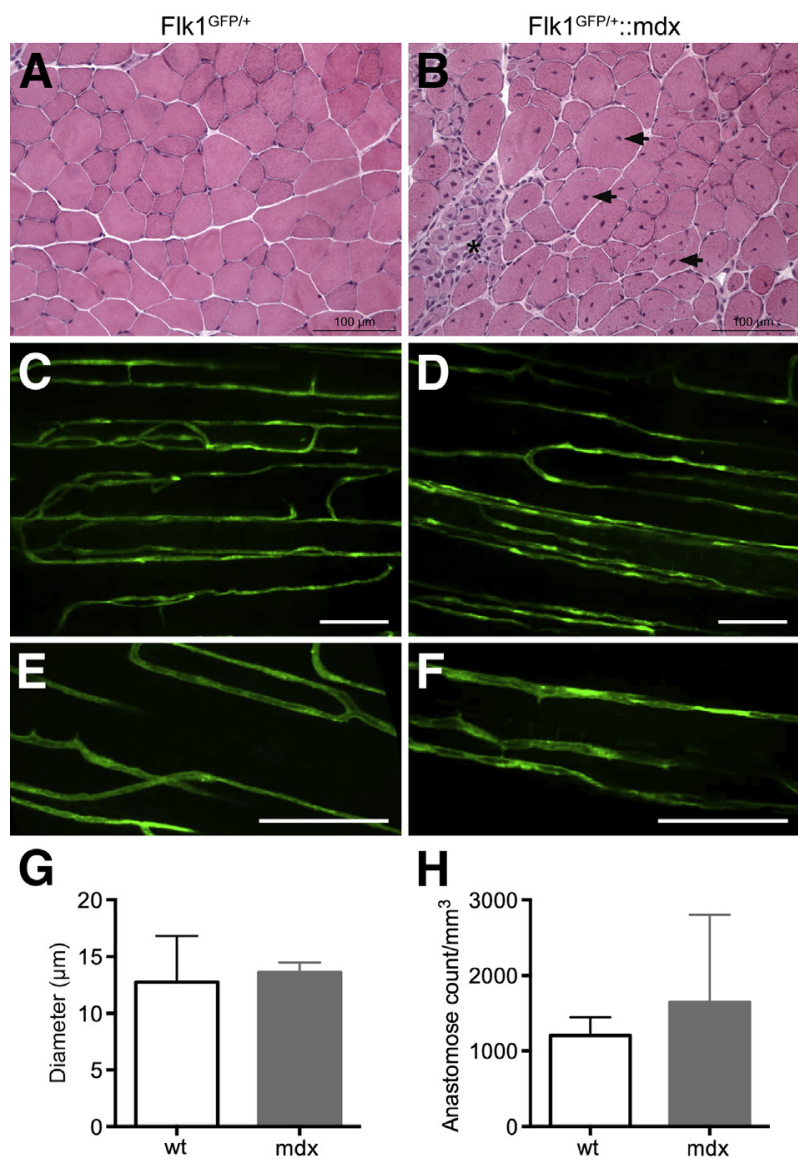

H

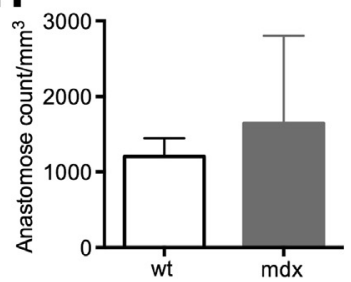

Figure 1 Normal microvascular network organization in 3-month-old $m d x$ mice. In contrast to wild-type mice (A), $m d x$ mice (B) display subacute lesions in gastrocnemius muscle, characterized by small inflammatory infiltrates (asterisk) associated with regenerated myofibers displaying central nuclei (arrows) (hematoxylin and eosin staining). Microvessel 3D organization of $\mathrm{Flk} 1^{\mathrm{GFP} /+}(\mathbf{C}$ and $\mathbf{E})$ and $\mathrm{Flk} 1^{\mathrm{GFP} /+}:: m d x(\mathbf{D}$ and $\mathbf{F})$ mice: normal blood microvessel organization, with microvessels regularly scattered along myofibers $(\mathbf{C}-\mathbf{F})$. Morphometric analyses reveal similar diameter $(\mathbf{G})$ and anastomose count $/ \mathrm{mm}^{3}(\mathbf{H})$ between microvessels from wild-type (wt) and $m d x$ mice. $N=3(\mathbf{G}$ and $\mathbf{H})$. Scale bar $=50 \mu \mathrm{m}(\mathbf{C}-\mathbf{F})$. GFP, green fluorescent protein.

arteriole density (Figure 3, I, J, and L). Collectively, these results highlighted a normal microvascular network organization in muscles of both groups, but a mild decrease in terminal arteriole density in $m d x$ mice.

The capillary-to-fiber perimeter exchange index has been used to calculate the contact surface area between capillaries and myofibers. It provides an indirect quantitative criterion to evaluate movement of oxygen from capillaries to muscle fibers. ${ }^{22}$ The capillary-to-fiber perimeter exchange index was not affected in young-adult $m d x$ mice (Figure $2 \mathrm{~F}$ ).

Because almost no alteration of the microvascular network was detected at the morphological level, we investigated the expression of angiogenesis-related mRNA [VEGF and its receptors Flk1 and Flt1, CD31, Ang1, Ang2, Tie1, Tie2 receptors, and neuronal NOS (nNOS)] (Figure 4A). We did not observe any significant modification of mRNA expression in young-adult $m d x$ mice, suggesting no stimulation of the angiogenesis process. In contrast, nNOS expression was significantly decreased in young-adult $m d x$ mice.

\section{Pericyte Density Is Similar But SC Count Increases in Young-Adult $m d x$ Mice}

By using immunohistochemistry analysis, we focused on important partners of endothelial cells: pericytes and SCs. Concerning pericytes $\left(\mathrm{NG}_{2}{ }^{+}\right.$cells located at the periphery of blood vessels in muscle sections ${ }^{23}$ ), no difference in density per $\mathrm{mm}^{2}$ was detected between wt $(151.6 \pm 14.3$ pericytes/ $\left.\mathrm{mm}^{2}, n=5\right)$ and $m d x\left(154.3 \pm 21.2\right.$ pericytes $\left./ \mathrm{mm}^{2}, n=5\right)$ mice (Figure 3, I-K). SCs $\left(\mathrm{Pax}^{+}\right.$cells) are in a close relationship with endothelial cells, and coupling between myogenesis and angiogenesis takes place concomitantly during muscle regeneration. ${ }^{11}$ In young-adult $m d x$ mice, we demonstrated, by using immunofluorescence, an increase in SC count per $\mathrm{mm}^{2}$ (wt: $14.5 \pm 0.3 \mathrm{SCs} / \mathrm{mm}^{2}, n=4 ; m d x$ :
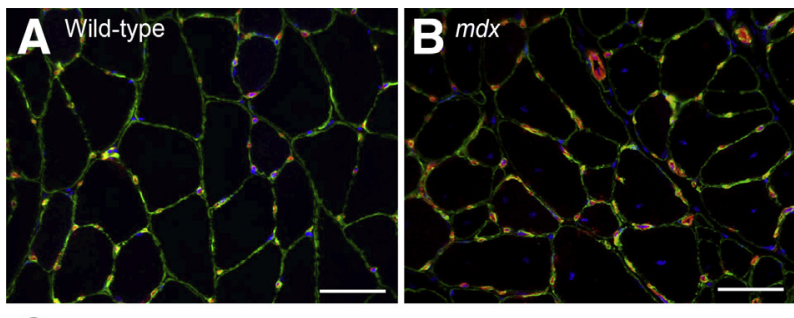

C
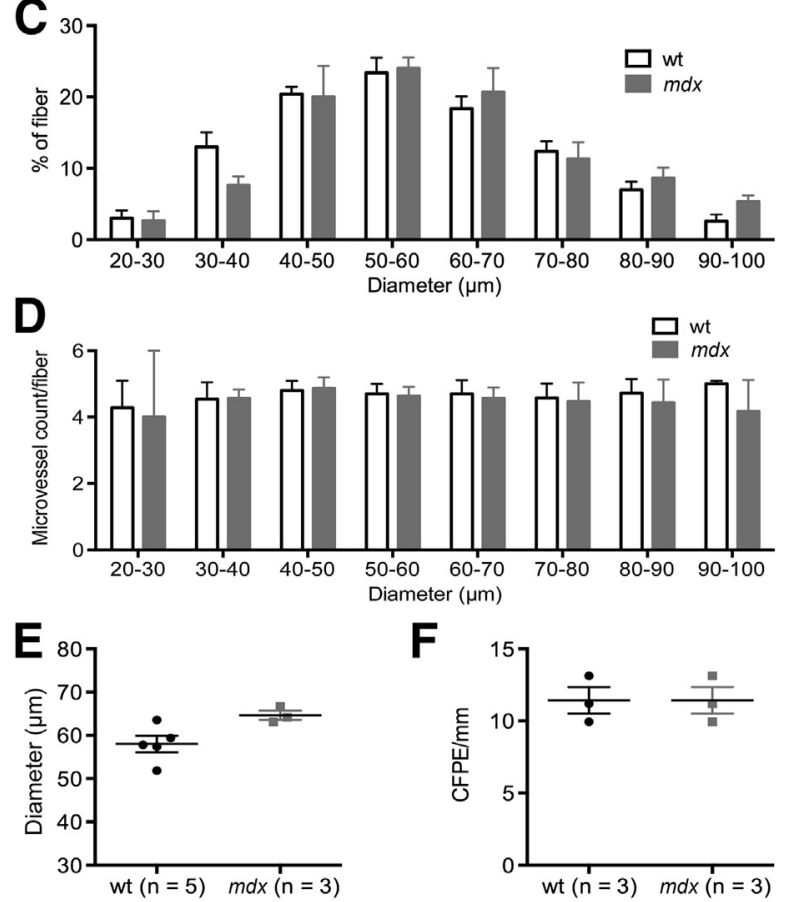

Figure 2 Microvessel morphometry in 3-month-old mice. A and $\mathbf{B}$ : Young-adult wild-type $(n=5)$ and $m d x(n=3)$ mice display similar microvessel distribution in gastrocnemius muscle [laminin-fluorescein isothiocyanate and CD31-tetrarhodamine isothiocyanate immunohistochemistry to label basal lamina (green) and blood vessels (red)]. Fiber size repartition (C), microvessel count per fiber (D), microvessel diameter (E), and capillary-to-fiber perimeter exchange index (CFPE; F) are shown. Scale bar $=50 \mu \mathrm{m}(\mathbf{A}$ and $\mathbf{B})$. 


\section{Satellite cells}
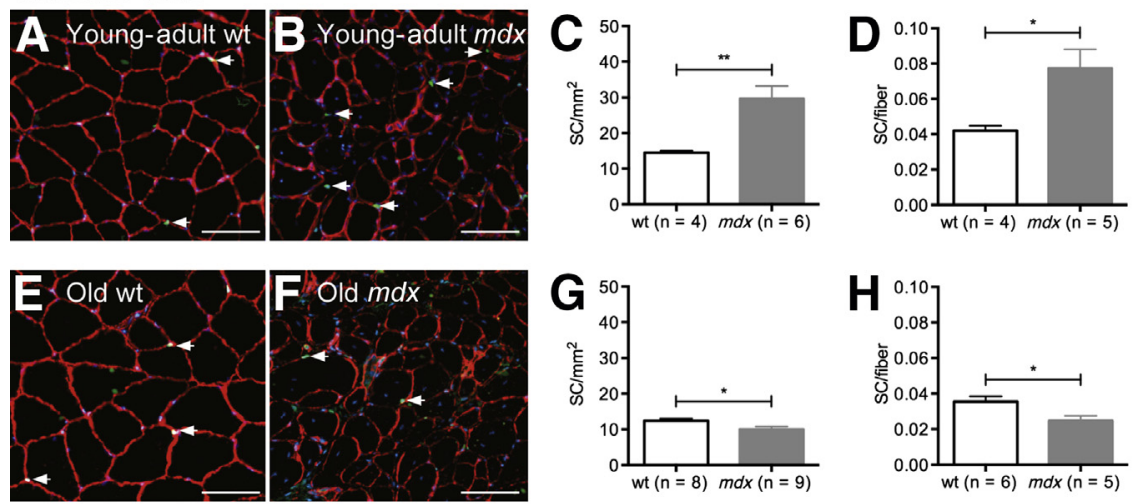

Pericytes and Terminal Arterioles
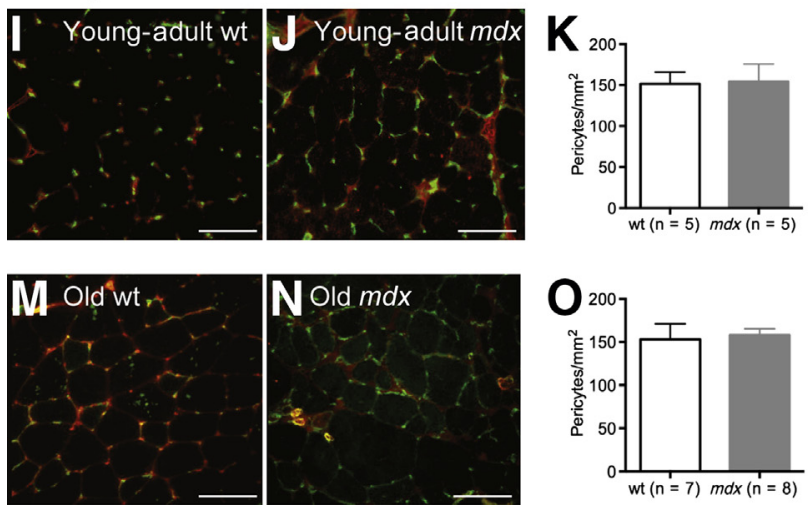

$\left.29.7 \pm 3.5 \mathrm{SCs} / \mathrm{mm}^{2}, n=6 ; P<0.01\right)$ and per fiber (wt: $0.04 \pm 0.01 \mathrm{SCs} /$ fiber, $n=4 ; m d x: 0.07 \pm 0.01 \mathrm{SCs} /$ fiber, $n=5 ; P<0.05)$, in comparison to wt (Figure 3, A-D).

\section{Muscle Blood Perfusion Is Modified in Young-Adult $m d x$ Mice}

In accordance with our previous observations (P.G. Carlier, unpublished data), profiles of reactive hyperemia were significantly different in $m d x(n=6)$ and wt $(n=9)$ mice $\left(P<10^{-6}\right.$ with analysis of variance) (Figure 5A). The
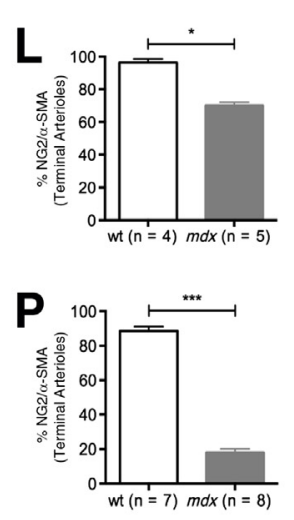

Figure 3 Satellite cells (SCs), terminal arterioles, and pericytes are affected in $m d x$ mice. A, B, $\mathbf{E}$, and $\mathbf{F}$ : The pool of SCs was analyzed by immunohistochemistry (arrows) [Pax7-fluorescein isothiocyanate (FITC) and laminin-Cy3]. SC density increases in young-adult $m d x$ mice (C and $\mathbf{D}$ ), whereas the SC pool depletes significantly in old $m d x$ mice ( $\mathbf{G}$ and $\mathbf{H}$ ). $\mathbf{I}-\mathbf{K}$ and $\mathbf{M}-\mathbf{0}$ : Pericyte density, assessed using neuron-glial antigen 2 immunolabeling (neuron-glial antigen 2-FITC), is similar for all groups at all ages. Analysis of the expression of smooth muscle actin (SMA) by perivascular smooth muscle cells, surrounding terminal arterioles ( $\alpha$-SMA-Cy 3$)$, shows a decrease of $26 \%$ $\alpha$-SMA expression for young-adult $m d x$ mice in comparison to wild-type (wt) animals (I, $\mathbf{J}$, and $\mathbf{L}$ ), reaching $70 \%$ loss for old $m d x(\mathbf{M}, \mathbf{N}$, and $\mathbf{P})$. ${ }^{*} P<0.05,{ }^{*} P<0.01$, and ${ }^{* * *} P<0.001$. Scale bar $=25 \mu \mathrm{m}(\mathbf{A}, \mathbf{B}, \mathbf{E}, \mathbf{F}, \mathbf{I}, \mathbf{J}, \mathbf{M}$, and $\mathbf{N})$.
A

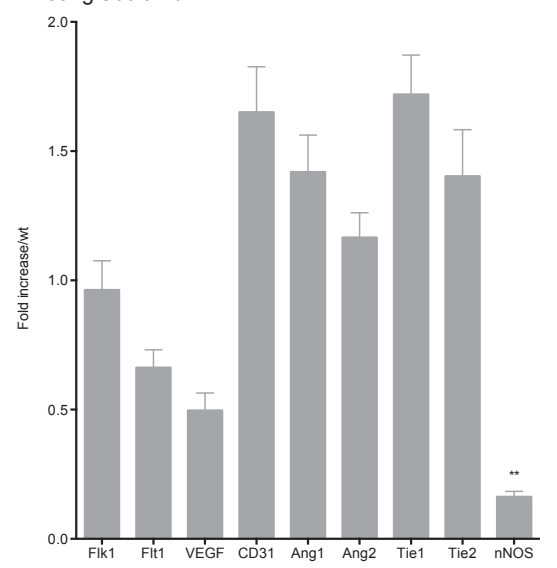

B

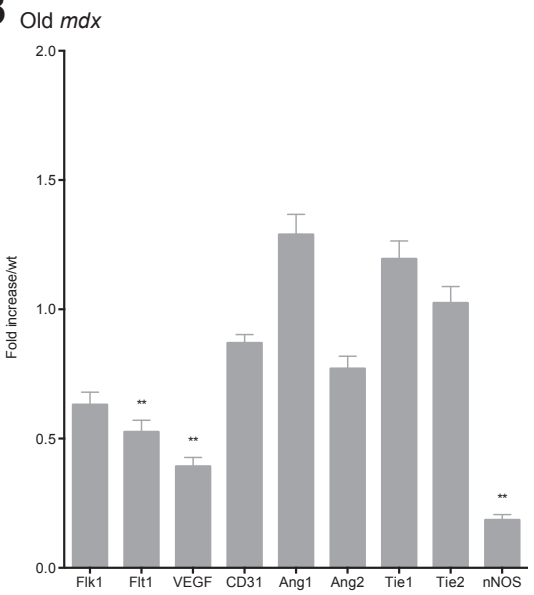

Figure 4 Analysis of angiogenesis-related gene expression by real-time quantitative $P C R$ (qPCR). Total RNA was extracted, and CDNA was analyzed by $q P C R$. Gene expression was measured in the gastrocnemius of young-adult (A) and old (B) $m d x$ mice. Results were normalized relative to the expression of the 18S rRNA housekeeping gene. A statistical difference was observed between $m d x$ and wild-type (wt) mice from the same age. Data are presented as means \pm SEM ( $A$ and B). ${ }^{* *} P<0.01$. nNOS, neuronal nitric oxide synthase; VEGF, vascular endothelial growth factor. 


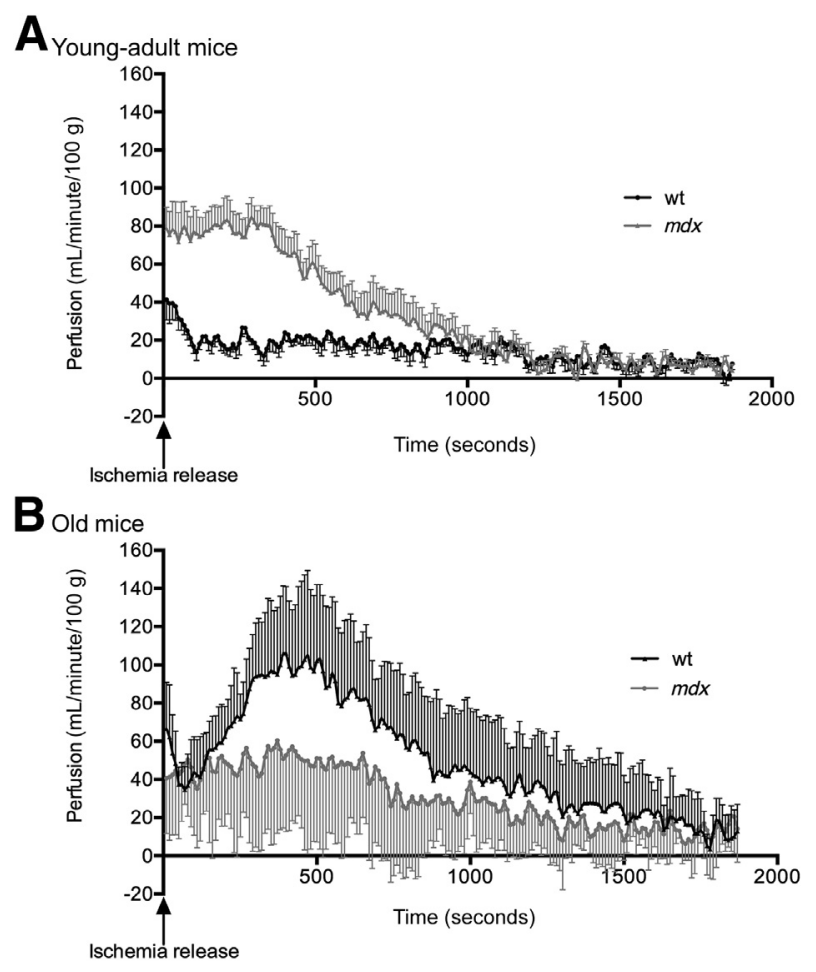

Figure 5 Muscle blood perfusion during ischemia-reperfusion. After release of ischemia, a rapid and important increase in perfusion is detected. A: Different profiles of perfusion are obtained in young-adult mice: total perfusion is higher in $m d x$ mice, and a first peak of perfusion, followed by a rapid decrease in muscle perfusion, is only detected in wild-type mice. B: A first peak, similar to what is observed in young-adult wild-type mice, is also observed in 12-month-old control animals. This first peak does not exist in $m d x$ mice that also displayed a reduced perfusion, with a maximum perfusion equivalent to half the value observed in wild-type mice during the hyperemia phase. Because the release of ischemia induced movements of the leg, images affected by these movement artifacts are removed from analysis of muscle perfusion. $n=9$ (A, wt); $n=6(\mathbf{A}, m d x) ; n=7$ (B, wt); $n=5(\mathbf{B}, m d x)$.

global volume repaid after ischemia was significantly higher in $m d x$ mice (wt: $474.3 \pm 216.3 \mathrm{~mL} / 100 \mathrm{~g} ; m d x$ : $1017.0 \pm 369.2 \mathrm{~mL} / 100 \mathrm{~g} ; P<0.05)$. The response to ischemic stress was, therefore, different and enhanced in young-adult $m d x$ mice, although almost no morphological modification of microvessels was detected.

\section{Muscle Bioenergetics in Young-Adult Mice}

Muscle bioenergetics in young-adult mice are summarized in Table 2.

At rest, $m d x$ mice displayed a slightly higher $\mathrm{Pi} / \mathrm{PCr}$ ratio compared with wt, which reflects an increase in ADP concentration in dystrophic mice. In addition, a lower $\mathrm{PCr} /$ $\gamma$ ATP ratio was observed in $m d x$ mice, reflecting a decrease in metabolically functional muscle tissue.

The 30-minute ischemic stress induced a higher $\mathrm{Pi} / \mathrm{PCr}$ ratio in $m d x$ mice, although $\mathrm{PCr}$ depletion tended to be accelerated compared with wt $(m d x: \Delta \mathrm{PCr}=65 \% \pm 9 \%$; wt: $\Delta \mathrm{PCr}=58 \% \pm 6 \% ; P=0.09$ ).
At reactive hyperemia, release revealed a significant acceleration of $\mathrm{PCr}$ resynthesis rate in $m d x$ mice compared with wt, reflecting higher mitochondrial ATP production in the $m d x$.

However, contrarily to wt, combined ${ }^{31} \mathrm{P}$-NMRS and perfusion results showed a tight correlation between time of creatine rephosphorylation $(\tau \mathrm{PCr})$ and various parameters reflecting perfusion: maximum perfusion $\left(r^{2}=0.66\right.$, $P<0.05)$ and time-perfusion integrals $\left(r^{2}=0.99\right.$, $P<0.001$ until 30 seconds; $r^{2}>0.93, P<0.01$ until 150 seconds) (Figure 6). In wt, none of the correlations between $\tau \mathrm{PCr}$ and perfusion were significant.

In summary, phosphate metabolism was accelerated during ischemia in 3-month-old $m d x$ mice. At recovery, mitochondrial oxidative rephosphorylation was unexpectedly faster and perfusion was increased in comparison to age-matched control mice. Moreover, perfusion in $m d x$ was directly related to mitochondrial ATP production. This is unlike a normal healthy case, in which a luxury perfusion is observed and is neither limiting nor correlated to $\tau \mathrm{PCr}$.

\section{Alteration of Microvascular Network Organization in Old Flk $1^{\mathrm{GFP} /+}:$ :mdx Mouse}

Old $m d x$ mice displayed marked histological lesions: some already observed in young adult as anisocytosis or centrally nucleated myofibers, and others included persistence of chronic inflammation and presence of endomysial/perimysial fibrosis (Figure 7, A-D). The microvascular network was as well organized in old $\mathrm{Flk} 1^{\mathrm{GFP} /+}$ as in young-adult mice (Figure 7, E and G). In contrast, Flk $1^{\mathrm{GFP} /+}:: m d x$ mice displayed significant alterations, characterized by a marked increase in tortuosity and irregular scattering of microvessels (Figure 7, F and H). Microvessel diameter was similar in both groups (12 $\mu \mathrm{m}$ thick) (Figure 7I), but we identified a higher anastomose count, from $>50,000$ anastomoses $/ \mathrm{mm}^{3}$ for $\mathrm{Flk} 1^{\mathrm{GFP} /+}:: m d x$ mice to $<1000$ anastomoses $/ \mathrm{mm}^{3}$ for control Flk1 ${ }^{\mathrm{GFP} /+}(P<0.01)$ (Figure $\left.7 \mathrm{~J}\right)$. Collectively, these results

Table 2 Energetic Metabolism Analysis from ${ }^{31} \mathrm{P}$-Spectroscopy in Young-Adult Mice

\begin{tabular}{lcc}
\hline Variable & wt $(n=9)$ & $m d x(n=6)$ \\
\hline$\Delta \mathrm{PCr}(\%)$ & $58 \pm 6$ & $65 \pm 9$ \\
$\tau \mathrm{PCr}$ (seconds) & $118 \pm 34$ & $76 \pm 34^{*}$ \\
$\mathrm{pH}$ at rest & $7.20 \pm 0.04$ & $7.17 \pm 0.03$ \\
$\mathrm{pH}$ end ischemia & $7.00 \pm 0.08$ & $6.98 \pm 0.03$ \\
$\mathrm{Pi} / \mathrm{PCr}$ at rest & $0.08 \pm 0.03$ & $0.10 \pm 0.01^{*}$ \\
$\mathrm{Pi} / \mathrm{PCr}$ end ischemia & $0.93 \pm 0.25$ & $1.71 \pm 0.52^{*}$ \\
$\mathrm{PCr} / \mathrm{ATP} \gamma$ at rest & $3.39 \pm 0.25$ & $3.01 \pm 0.27^{*}$ \\
$\mathrm{PCr} / \mathrm{ATP} \gamma$ end ischemia & $1.80 \pm 0.62$ & $1.39 \pm 0.51$ \\
\hline
\end{tabular}

Ischemia stress was sufficient because the mean depletion of $\mathrm{PCr}$ for wt and $m d x$ mice was $>50 \%$. $\mathrm{Pi} / \mathrm{PCr}$ levels at rest and after ischemia were higher in $m d x$ compared with wt mice, whereas PCr/ATP $\gamma$ at rest was lower. ${ }^{*} P<0.05$.

$\mathrm{PCr}$, phosphocreatine; $\mathrm{Pi}$, inorganic phosphate; $\tau \mathrm{PCr}$, time of creatine rephosphorylation; wt, wild type. 
A Correlation maximal perfusion/ $/ \mathrm{PCr}$ Young-adult wt mice
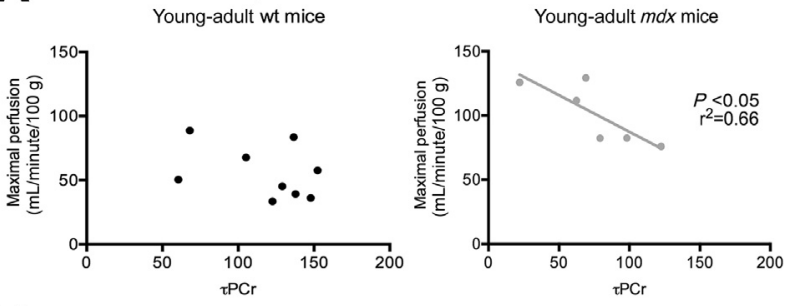

B Correlation perfusion integral until $30 \mathrm{sec} / \tau \mathrm{PCr}$ Young-adult wt mice

Young-adult $m d x$ mice
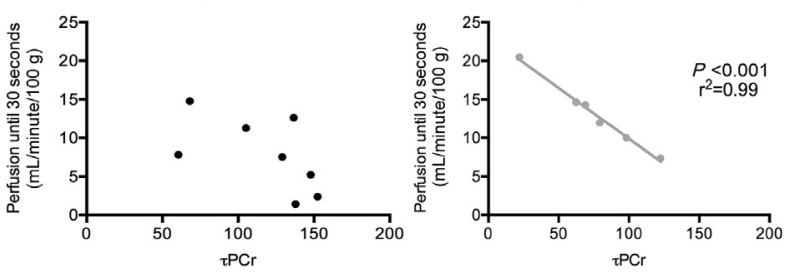

Figure 6 Correlation between perfusion and time of creatine rephosphorylation ( $\tau \mathrm{PCr}$ ) in 3-month-old mice. Correlation between $\tau \mathrm{PCr}$ and maximal perfusion (A) or time-perfusion integrals until 30 seconds (B) is significant in $m d x$ mice, with a coefficient of determination $r^{2}$ of 0.66 and 0.99 , respectively. In wild-type (wt) mice, none of the correlations is significant.

pointed to an anarchic blood vessel organization in this context of dystrophinopathy.

Immunofluorescence analyses showed that myofiber cross-section mean diameter was smaller in $m d x$ mice ( $m d x$ : $47.4 \pm 4.2 \mu \mathrm{m}$; wt: $61.2 \pm 3.9 \mu \mathrm{m} ; P<0.001)$ (Figure 8, A-C); the smaller myofibers $(<50 \mu \mathrm{m})$ were clearly undervascularized (Figure $8 \mathrm{E}$ ), were perinucleated (Figure 8G), and represented almost $60 \%$ of total muscle fibers in $m d x$ mice in contrast to $35 \%$ in controls (Figure 8D). Alterations were also detected at the terminal arteriole level, because a loss of $70 \%$ of $\alpha$-SMA expression was detected in old $m d x$ mice (wt: $88.6 \% \pm 2.4 \%, n=7$; $m d x: 18.0 \% \pm 2.1 \%, n=8 ; P<0.001)$, suggesting a marked decrease in terminal arteriole density (Figure 3, M, $\mathrm{N}$, and $\mathrm{P}$ ). These data suggested either a progressive degradation of tissue with no maintenance of microvascular network with time or a defect of neoangiogenesis. The capillary-to-fiber perimeter exchange index was not affected in old mice (Figure 8F).

Angiogenesis-related mRNA expression analysis revealed a collapse of VEGF expression and its decoy receptor, Flt1 (Figure 4B). As observed in young-adult mice, nNOS was also significantly decreased in old $m d x$ mice.

Collectively, these results pointed out severe alterations of microvessel organization, especially around small/ atrophic myofibers, associated with alteration of angiogenesis, suggesting chronic alteration of endothelial-myogenic cell interface.

\section{Pericytes and SCs in Old $m d x$ Mice}

The density of pericytes was similar between wt and $m d x$ mice (Figure 30), but, in contrast to young-adult $m d x$ mice, a decrease in SC count was observed for old $m d x$ mice (wt: $12.4 \pm 0.6 \mathrm{SCs} / \mathrm{mm}^{2}, n=8$; $\left.m d x: 10.0 \pm 0.8 \mathrm{SCs} / \mathrm{mm}^{2}, n=9 ; P<0.05\right)$ (Figure 3, E-H).
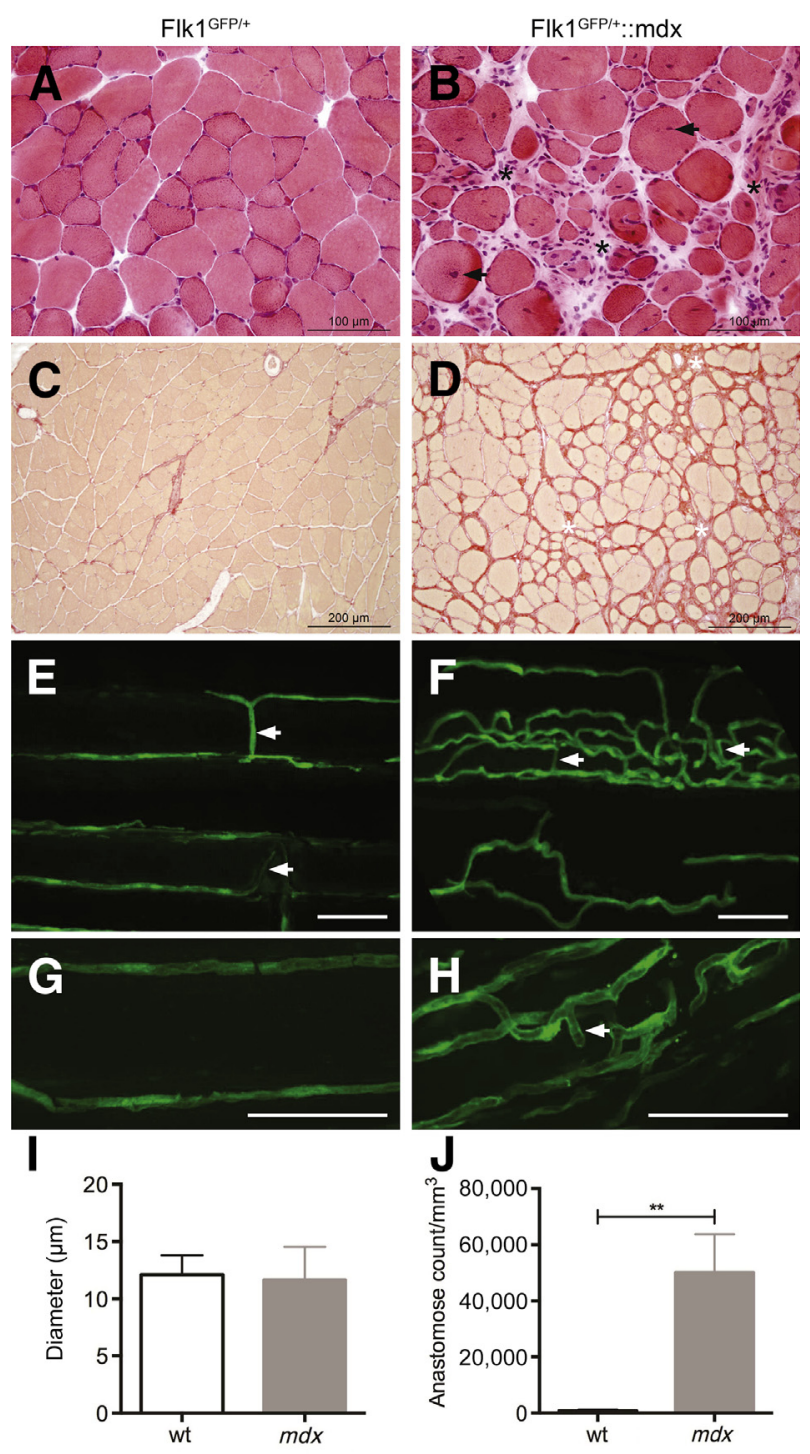

Figure 7 Alteration of microvascular network in 12-month-old $m d x$ mice. Twelve-month-old wild-type mice display histologically normal muscles (A), with no fibrosis (C), and regularly scattered microvessels along myofibers, with few anastomoses (E, G, and $\mathbf{J})$. In contrast, 12-month-old $m d x$ mice display chronic histological lesions (B), characterized by multifocal inflammatory infiltrates (mostly macrophages), included in endomysial collagen tissue (fibrosis; asterisks), associated with a marked variation in myofiber size (anisocytosis) and the presence of atrophic and regenerating myofibers displaying centrally located nuclei (black arrows). Sirius red staining and fluorescence microscopy reveal a moderate to marked endomysial fibrosis (D) and microvascular network alterations ( $\mathbf{F}$ and $\mathbf{H}$ ) characterized by irregularly scattered tortuous microvessels. Even if microvessel diameter is similar between $m d x$ and wild-type (wt) mice (I), a clear increase in anastomose count $/ \mathrm{mm}^{3}$ is detected for old $m d x$ mice (white arrows) (J). A and B: Hematoxylin and eosin staining. C and D: Sirius red staining (specific for collagen staining). ${ }^{* *} P<0.01 . n=8$ (I and $\mathbf{J}, w \mathrm{wt}) ; n=5$ (I and $\mathbf{J}, m d x)$. Scale bar $=50 \mu \mathrm{m}(\mathbf{E}-\mathbf{H})$. GFP, green fluorescent protein. 


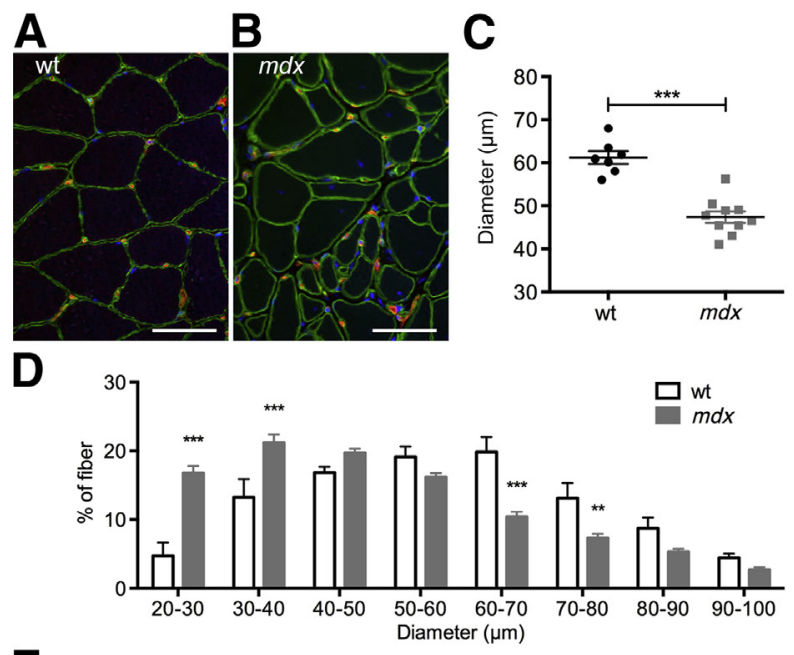

E

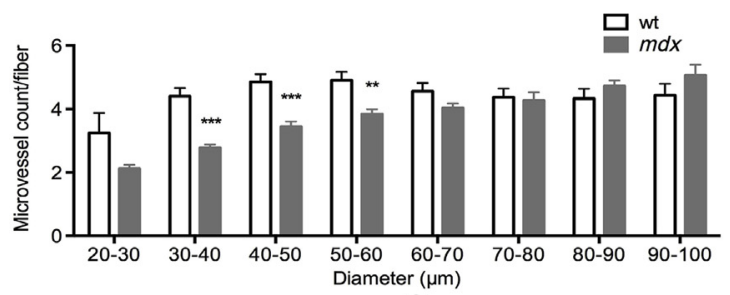

$\mathbf{F}$

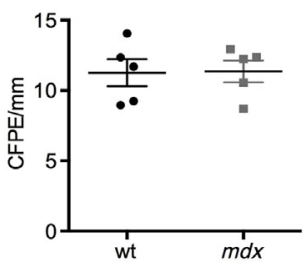

G

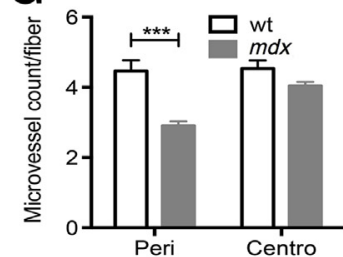

Figure 8 Twelve-month-old $m d x$ mice display atrophic myofibers with low capillarization and terminal arteriole density. A-C: Anisocytosis is more pronounced in old $m d x$ mice, with the presence of small atrophic myofibers (laminin-fluorescein isothiocyanate and CD31-tetrarhodamine isothiocyanate immunohistochemistry). D: Atrophic myofibers (with a diameter up to $60 \mu \mathrm{m}$ ) represent $>60 \%$ of the total myofibers in $m d x$ mice. E: These atrophic myofibers display fewer microvessels at their periphery. F: The distance between microvessels and myofibers, calculated using the capillary-to-fiber perimeter exchange index (CFPE) is similar in both groups. G: Small myofibers with low capillarization are mostly perinucleated (Peri) myofibers. ${ }^{* *} P<0.01,{ }^{* *} P<0.001 . n=7$ [A-E, wild type (wt)]; $n=$ $10(\mathbf{A}-\mathbf{E}, m d x) ; n=5(\mathbf{F}$, wt and $m d x$, and $\mathbf{G}$, wt); $n=8(\mathbf{G}, m d x)$. Scale bar $=50 \mu \mathrm{m}$ (A and B). Centro, centronucleated.

\section{Alteration of Muscle Perfusion in Old $m d x$ Mice}

Despite severe alterations in $m d x$ muscle microvascular network organization, at rest, no difference in muscle perfusion was observed between $m d x$ and wt mice $(m d x: 12.09 \pm 5.90 \mathrm{~mL} /$ minute per $100 \mathrm{~g}$; wt: $8.19 \pm 2.19$ $\mathrm{mL} /$ minute per $100 \mathrm{~g}$ ). After tourniquet release, rapid increase of perfusion was detected in muscles of the posterior hind limb compartment; this increase was significantly lower in old $m d x$ mice ( $m d x$ perfusion maximal value at 380 seconds after ischemia: $60.5 \pm 39.3 \mathrm{~mL} /$ minute per $100 \mathrm{~g}$; wt perfusion maximal value at 400 seconds after ischemia: $106.1 \pm 38.1 \mathrm{~mL} /$ minute per $100 \mathrm{~g} ; P<0.05$ ), in contrast to what was seen in young-adult mice.
Analysis of variance of perfusion time courses demonstrated differing profiles between wt and $m d x$ mice $\left(P<10^{-4}\right)$, with specific differences in the early phase of reperfusion. A similar initial peak of perfusion, as the one observed in young-adult wt mice, was detected in the old wt group, 20 seconds after ischemia, but was absent in $m d x$ mice (Figure 5B).

Thus, at 12 months, both $m d x$ and wt showed different profiles from young-adult animals (analysis of variance, $P<10^{-6}$ ), and in contrast to wt and young-adult $m d x$, old $m d x$ mice displayed a decrease in muscle perfusion and a modified perfusion profile after an ischemic stress.

\section{Muscle Bioenergetics in 12-Month-Old Mice}

Muscle bioenergetics in 12-month-old mice are summarized in Table 3.

At rest, no difference in $\mathrm{pH}$ was observed between wt $(n=7)$ and $m d x(n=5)$ mice, but hypoxic stress induced a significant acidosis in both groups $(P<0.005)$, more pronounced in $m d x$ (wt: $\Delta \mathrm{pH}=0.22 \pm 0.06 ; m d x: \Delta \mathrm{pH}=0.30 \pm 0.04 ; P<0.05$ ). Ischemia was associated with a significant increase in $\mathrm{PCr}$ depletion in old dystrophic mice compared with wt, although the difference in $\mathrm{Pi} / \mathrm{PCr}$ ratio between the two groups was not significant. Unlike in young-adult mice, the rephosphorylation rate was comparable in both groups. Indeed, $\tau \mathrm{PCr}$ was shorter in the old compared with the young-adult wt mice $(P<0.01)$, but was unchanged with age in the $m d x$ mice. Thus, no alteration of oxidative capacities was observed in old $m d x$ mice in response to hypoxic stress compared with age-matched control mice, despite reduced perfusion. In older mice (wt and $m d x$ ), no correlation was observed between $\tau \mathrm{PCr}$ and perfusion variables.

\section{Discussion}

Our study deciphers lesions of the muscle microvascular network, in a model of dystrophinopathy, by using a

Table 3 Energetic Metabolism Analysis from ${ }^{31} \mathrm{P}$-Spectroscopy in Old Mice

\begin{tabular}{lcc}
\hline Variable & wt $(n=7)$ & $m d x(n=5)$ \\
\hline$\Delta \mathrm{PCr}(\%)$ & $54 \pm 4$ & $63 \pm 2^{* *}$ \\
$\tau \mathrm{PCr}$ (seconds) & $66 \pm 25$ & $80 \pm 20$ \\
$\mathrm{pH}$ at rest & $7.16 \pm 0.07$ & $7.18 \pm 0.04$ \\
$\mathrm{pH}$ end ischemia & $6.94 \pm 0.04$ & $6.87 \pm 0.04^{*}$ \\
$\mathrm{Pi} / \mathrm{PCr}$ at rest & $0.08 \pm 0.04$ & $0.10 \pm 0.01$ \\
$\mathrm{Pi} / \mathrm{PCr}$ end ischemia & $1.24 \pm 0.40$ & $1.34 \pm 0.20$ \\
$\mathrm{PCr} / \mathrm{ATP} \gamma$ at rest & $2.98 \pm 0.35$ & $3.05 \pm 0.16$ \\
$\mathrm{PCr} / \mathrm{ATP} \gamma$ end ischemia & $1.20 \pm 0.35$ & $1.36 \pm 0.30$ \\
\hline
\end{tabular}

Ischemia stress was sufficient as the mean depletion of $\mathrm{PCr}$ for wt and $m d x$ mice was $>50 \%$. $\Delta \mathrm{PCr}$ is higher in $m d x$ mice; $\mathrm{pH}$ decreased for both wt and $m d x$ mice after ischemia, but $m d x$ mice experienced a more severe acidosis. Other energetic parameters did not change in our experimental conditions.

${ }^{*} P<0.05,{ }^{*} * P<0.01$.

$\mathrm{PCr}$, phosphocreatine; $\mathrm{Pi}$, inorganic phosphate; $\tau \mathrm{PCr}$, time of creatine rephosphorylation; wt, wild type. 
combination of state-of-the-art histology/morphometry techniques and a totally noninvasive functional approach. This experimental paradigm, combining histopathology and multiparametric functional NMR, is clearly relevant for clinical diagnosis and research; it allowed us to associate, for the first time, the fine 3D alterations of muscle microvascular network with functional repercussions on muscle.

\section{Importance of Age in $m d x$ Mouse Model}

Concerning the animal model, previous studies used 6week-old to 6-month-old $m d x$ mice, ${ }^{12,14,24}$ which display few chronic lesions with no fibrosis, in contrast to what happens in humans. ${ }^{16} \mathrm{We}$, therefore, worked on 12-monthold $m d x$ mice, displaying persistence of endomysial inflammation and fibrosis, more representative of human DMD and, thus, more relevant for chronic myopathy and DMD pathophysiology study, in contrast to young-adult $m d x$ mice displaying no chronic lesions. We demonstrated the following: i) strong alterations of microvascular network structure associated with reduced muscle perfusion in old $m d x$ mice, ii) functional increase in muscle perfusion and mitochondrial oxidative phosphorylation with normal microvascular network organization in young-adult $m d x$ mice, and iii) a different impact of age on wt and $m d x$ mouse muscles.

In young-adult and old wt mice, no alteration could be detected in muscle histology or microvascular network organization. Perfusion is primarily regulated by smooth muscles that control blood flow distribution and capillary recruitment. ${ }^{25}$ Capillary resistance, at rest, plays only a minor role in perfusion regulation. By using ischemiareperfusion, we provoke maximal arteriolar dilatation to limit arteriolar resistance, and thus the microvessel network becomes predominant in control of muscle perfusion. ${ }^{26}$ Analysis of perfusion profiles revealed the existence of a peak of perfusion in the first seconds after ischemia release, for young-adult and old wt mice. This initial peak suggests specific regulation of perfusion in the early phase after ischemia release, probably coordinated by perivascular smooth muscles and/or pericytes. ${ }^{27}$

\section{Early Loss of Terminal Arterioles and nNOS Modifies Perfusion Profile}

Surprisingly and in contrast to previous studies describing decreased vascular density, ${ }^{12,14}$ we did not detect any alteration in vascular network 3D organization in youngadult $m d x$ mice. However, muscle postischemic perfusion was higher than in age-matched control mice, and time resolution of multiparametric functional NMR allowed to demonstrate the absence of the initial peak of perfusion. In the same time, we also demonstrated a $26 \%$ loss of $\alpha$-SMA expression in young-adult $m d x$ muscle (and $>70 \%$ loss in old $m d x$ ), suggesting a decrease in perivascular SMCs, responsible for part of these deleterious effects. It has been demonstrated in vivo that the reexpression of dystrophin only in SMCs significantly ameliorates vasoregulation in $m d x$ mice, ${ }^{28}$ confirming the importance of perivascular cells (eg, pericytes, smooth muscle) in blood flow regulation. One of the possible key factors is NO production alteration $^{29}$ or impairment of nNOS, ${ }^{29-31}$ probably explaining the significant decrease in nNOS expression in both youngadult and old $m d x$ mice, in our study. Concerning pericytes, Yemisci et $\mathrm{al}^{27}$ demonstrated in the brain, after a 2-hour ischemic stress, that pericytes remain contracted despite successful reopening of blood flow, impairing microcirculatory reflow. These experiments were performed ex vivo, and no functional in vivo validation was performed. Our data seem, therefore, to highlight functional alterations of smooth muscles and/or pericytes after ischemic stress. This alteration is severe enough to significantly affect perfusion profiles between control and $m d x$ mice, and we are currently performing new experiments to better understand the effect of an absence of dystrophin in perivascular cells and their involvement in dystrophinopathy pathophysiology.

Old Flk1 $1^{\mathrm{GFP} /+}:: m d x$ model allowed us to highlight disorganization of microvascular network. A marked increase in microvessel tortuosity, an irregular scattering, and an increase in anastomose count were observed. The existence of these highly abundant anastomoses suggests that radial and longitudinal (parallel to myofibers) blood flow is important and, in turn, that longitudinal flow is abnormally heterogeneous, with microvessel longitudinal resistance being likely to vary a lot from microvessel to microvessel, which would be the driven force for collateral flow.

\section{Alteration of the Angiogenesis-Myogenesis Coupling in DMD}

Considering the close association between microvessels and myofibers, we demonstrated in old $m d x$ mice that $>60 \%$ of myofibers were atrophic with peripheral nuclei and displayed fewer microvessels at their periphery, resulting in a global undercapillarization and loss of terminal arterioles. In parallel, NMR analysis revealed a twofold decrease in perfusion after ischemia release. The significant decrease of microvessel (capillary and terminal arteriole) density around small myofibers is likely responsible for these functional alterations. Our data are, thus, in agreement with other studies demonstrating the effect of age on dystrophinopathy pathophysiology. ${ }^{15,24}$ Our hypothesis is that interaction between angiogenesis and myogenesis could be affected in old $m d x$ mice; the increasingly scarce microvessels would provoke an alteration of myofiber regeneration that, in turn, could lead to impairment of the remaining microvascular network support, maintaining a vicious circle. With this idea, we focused on the dynamic of SC density in the muscle tissue. Although SC density in young-adult $m d x$ mice was increased, probably because of the stimulation of muscle regeneration, it collapsed in old $m d x$ mice, with pathology evolution, suggesting a worsening of the situation 
and an increase in the severity of chronic muscle lesions. A decline in SC number and activity has already been observed with age in $m d x$ mice, in association with attenuated Notch signaling transduction. ${ }^{32}$ Christov et $\mathrm{al}^{11}$ already introduced the idea that angiogenesis and myogenesis are coupled during muscle regeneration, processes involving several growth factors, such as VEGF. In our study, we also observed modifications of VEGF and its receptor, Flt1, expression profiles. Flt1 is the decoy receptor of VEGF, ${ }^{33}$ acting as a negative regulator of endothelial cell growth and differentiation. A previous study demonstrated that $m d x$ mice knockout for the Flt1 receptor $\left(m d x:\right.$ Flt $\left.1^{+/-}\right)$ presented an improved muscle histology associated with a better muscle perfusion and force production compared with $m d x$ mice. ${ }^{34}$ These data underline the link between vascular remodeling and muscle regeneration, even in severe chronic diseases. Concerning VEGF, the twofold decreased expression, detected in old $m d x$ mice, was in accordance with previous studies demonstrating that treatment with VEGF strongly ameliorates the $m d x$ phenotype, with improvement of functional parameters, an increase in capillary density, improved muscle regeneration, and a decrease in interstitial fibrosis. ${ }^{35,36}$ Fibrosis is incidentally a key parameter influencing perfusion, and is increased in DMD. ${ }^{10}$ However, fibrosis might not be the most limiting factor to perfusion, because it only represents $10 \%$ of old $m d x$ mice muscle tissue in our study. Moreover, the distance between capillaries and myofibers, generally modified with endomysial fibrosis, ${ }^{22}$ is similar between young-adult and old wt and $m d x$ mice.

The in vivo increase of postischemic muscle perfusion with old age in wt animals was reproducible in different mouse strains, but no explanation is currently put forward, whereas the effect of aging on perfusion is still debated, even in humans. ${ }^{37,38}$

\section{Compensatory Mechanisms to Prevent Energetic Metabolism Alterations}

In parallel to perfusion analysis, acquisition of ${ }^{31} \mathrm{P}$-spectroscopy revealed moderate energetic metabolism alterations, in agreement with previous literature, ${ }^{39-41}$ and contrarily to what might be expected from alterations of enzymatic activities or defects of mitochondrial localization in vitro. Compensatory mechanisms must, thus, exist in dystrophic muscle. ${ }^{39-41}$

As for perfusion, anomalies in phosphorus metabolites in wt animals depended on age, as already evoked in early studies of $m d x$ metabolism. ${ }^{40,42}$ Anomalies at rest were more marked in younger $m d x$ : $\mathrm{Pi} / \mathrm{PCr}$ reflecting resting ADP production was increased, whereas $\mathrm{PCr} / \mathrm{ATP}$ proportional to functional muscle was reduced $(-11 \%)$, coherently with other reports $^{39-41}\left(-50 \%\right.$ or more in DMD children $\left.{ }^{43}\right)$.

Unlike a recent study in 3-month-old $m d x$ mice, ${ }^{44}$ where 10-minute ischemia was used as stress protocol, depletion was greater after 30-minute ischemia in both young-adult and old $m d x$. During prolonged ischemia, two energetic pathways are activated to supply ATP demand: ATP-PCr system and glycolytic pathway. Production of ATP directly from $\mathrm{PCr}$ consumption is small; it is, therefore, unlikely that $\mathrm{PCr}$ would be consumed to compensate for defective glycolytic pathway. The higher depletion observed in both young-adult and old $m d x$ could more likely reflect a higher ATP demand to maintain ionic homeostasis.

Confrontation between perfusion and metabolic data, obtained simultaneously by NMR, revealed that, despite strongly reduced perfusion in old $m d x$ mice, oxidative metabolism was preserved, suggesting existence of a luxury perfusion (ie, reserve of perfusion that can be eliminated without impact on muscle physiology), as previously evidenced in a model of peripheral artery disease. ${ }^{45}$ It generally explains the absence, or loose correlation, between perfusion and $\mathrm{PCr}$ recovery rates in wt animals and in old $m d x$. This contrasts with the tight correlation between initial perfusion and $\tau \mathrm{PCr}$ of young-adult $m d x$ mice, which display faster $\tau \mathrm{PCr}$ recovery and stronger perfusion than controls. By using optical spectroscopy to analyze myoglobin and hemoglobin oxygen desaturation in parallel to ${ }^{31} \mathrm{P}-\mathrm{NMRS}$, Percival et $\mathrm{al}^{44}$ observed strong uncoupling between ATP synthesis and oxygen consumption in 4-month-old $m d x$, dystrophic muscle, producing 39\% ATP less per oxygen consumed than controls. We might, thus, hypothesize that at this young age, increased perfusion might be a means to compensate for mitochondrial inefficiency.

\section{Conclusion}

In conclusion, we demonstrated strong structural and functional alterations in the muscle microvascular network of dystrophin-deficient $m d x$ mice, with an increasing severity in parallel to aging. Our approach combining 3D morphological analyses with noninvasive functional evaluation allowed us to better characterize the impact of histological lesions on tissue function. Collectively, our data pointed out that the vascular network has a key role in dystrophinopathy pathophysiology and would be an important target for the setup of new innovative therapeutic strategies.

\section{Acknowledgments}

We thank Prof. Romain K. Gherardi and Prof. Jérôme Authier (Hôpital Henri Mondor) and Prof. Shahragim Tajbakhsh (Institut Pasteur) for the scientific exchanges on muscle dystrophy pathophysiology, regeneration mechanisms, and experimental devices; Dr. Aurélien Mazeraud and Dr. Anne Danckaert (Institut Pasteur) for help in biostatistical analyses; and Patricia Flamant for technical support. Prof. Romain K. Gherardi (Hôpital Henri Mondor) and Alexander Medvinsky (Institute for Stem Cell Research, University of Edinburgh, Edinburgh, UK) provided the 
$m d x-4 \mathrm{Cv}$ with $\mathrm{C} 57 \mathrm{Bl} / 6$ background mice and Flk-1 ${ }^{\mathrm{GFP} /+}$ mice, respectively.

G.J., F.C., C.W., C.L., and P.G.C. designed experiments. C.L., B.M., A.M.-B., and D.B. performed experiments. G.J., F.C., P.G.C., C.W., B.M., and C.L. analyzed data. G.J., C.L., B.C., B.M., and C.W. wrote the paper. All authors approved the submitted and published manuscripts.

\section{References}

1. De Paepe B, De Bleecker JL: Cytokines and chemokines as regulators of skeletal muscle inflammation: presenting the case of Duchenne muscular dystrophy. Mediators Inflamm 2013, 2013:540370

2. Ennen JP, Verma M, Asakura A: Vascular-targeted therapies for Duchenne muscular dystrophy. Skelet Muscle 2013, 3:9

3. Shimizu-Motohashi Y, Asakura A: Angiogenesis as a novel therapeutic strategy for Duchenne muscular dystrophy through decreased ischemia and increased satellite cells. Front Physiol 2014, 5:50

4. Engel WK, Hawley RJ: Focal lesions of muscle in peripheral vascular disease. J Neurol 1977, 215:161-168

5. Rando TA: Role of nitric oxide in the pathogenesis of muscular dystrophies: a "two hit" hypothesis of the cause of muscle necrosis. Microse Res Tech 2001, 55:223-235

6. Koehler J: Blood vessel structure in Duchenne muscular dystrophy, I: light and electron microscopic observations in resting muscle. Neurology 1977, 27:861-868

7. Bradley WG, O'Brien MD, Walder DN, Murchison D, Johnson M, Newell DJ: Failure to confirm a vascular cause of muscular dystrophy. Arch Neurol 1975, 32:466-473

8. Gudrun B, Andrew GE, Boysen G, Engel AG: Effects of microembolization on the skeletal muscle blood flow: a critique of the microvascular occlusion model of Duchenne dystrophy. Acta Neurol Scand 1975, 52:71-80

9. Leinonen H, Juntunen J, Somer H, Rapola J: Capillary circulation and morphology in Duchenne muscular dystrophy. Eur Neurol 1979, 18: 249-255

10. Desguerre I, Mayer M, Leturcq F, Barbet JP, Gherardi RK, Christov C: Endomysial fibrosis in Duchenne muscular dystrophy: a marker of poor outcome associated with macrophage alternative activation. J Neuropathol Exp Neurol 2009, 68:762-773

11. Christov C, Chretien F, Abou-Khalil R, Bassez G, Vallet G, Authier FJ, Bassaglia Y, Shinin V, Tajbakhsh S, Chazaud B, Gherardi RK: Muscle satellite cells and endothelial cells: close neighbors and privileged partners. Mol Biol Cell 2007, 18:1397-1409

12. Loufrani L: Absence of dystrophin in mice reduces NO-dependent vascular function and vascular density: total recovery after a treatment with the aminoglycoside gentamicin. Arterioscler Thromb Vasc Biol 2004, 24:671-676

13. Landisch RM, Kosir AM, Nelson SA, Baltgalvis KA, Lowe DA: Adaptive and nonadaptive responses to voluntary wheel running by mdx mice. Muscle Nerve 2008, 38:1290-1303

14. Matsakas A, Yadav V, Lorca S, Narkar V: Muscle ERRgamma mitigates Duchenne muscular dystrophy via metabolic and angiogenic reprogramming. FASEB J 2013, 27:4004-4016

15. Straino S: Enhanced arteriogenesis and wound repair in dystrophindeficient mdx mice. Circulation 2004, 110:3341-3348

16. Grounds MD, Radley HG, Lynch GS, Nagaraju K, De Luca A: Towards developing standard operating procedures for pre-clinical testing in the mdx mouse model of Duchenne muscular dystrophy. Neurobiol Dis 2008, 31:1-19

17. Bertoldi D, Loureiro de Sousa P, Fromes Y, Wary C, Carlier PG: Quantitative, dynamic and noninvasive determination of skeletal muscle perfusion in mouse leg by NMR arterial spin-labeled imaging. Magn Reson Imaging 2008, 26:1259-1265
18. Baligand C, Gilson H, Menard JC, Schakman O, Wary C, Thissen JP, Carlier PG: Functional assessment of skeletal muscle in intact mice lacking myostatin by concurrent NMR imaging and spectroscopy. Gene Ther 2010, 17:328-337

19. Raynaud JS, Duteil S, Vaughan JT, Hennel F, Wary C, LeroyWillig A, Carlier PG: Determination of skeletal muscle perfusion using arterial spin labeling NMRI: validation by comparison with venous occlusion plethysmography. Magn Reson Med 2001, 46:305-311

20. Taylor DJ, Bore PJ, Styles P, Gadian DG, Radda GK: Bioenergetics of intact human muscle: a 31P nuclear magnetic resonance study. Mol Biol Med 1983, 1:77-94

21. Granger DN, Senchenkova E: Integrated Systems Physiology-From Cell to Function. Inflammation and the Microcirculation. San Rafael, CA, Morgan and Claypool Life Sciences, 2010

22. Hepple RT: A new measurement of tissue capillarity: the capillaryto-fibre perimeter exchange index. Can J Appl Physiol 1997, 22:11-22

23. Wanjare M, Kusuma S, Gerecht S: Perivascular cells in blood vessel regeneration. Biotechnol J 2013, 8:434-447

24. Palladino M, Gatto I, Neri V, Straino S, Smith RC, Silver M, Gaetani E, Marcantoni M, Giarretta I, Stigliano E, Capogrossi M, Hlatky L, Landolfi R, Pola R: Angiogenic impairment of the vascular endothelium: a novel mechanism and potential therapeutic target in muscular dystrophy. Arterioscler Thromb Vasc Biol 2013, 33:2867-2876

25. Clifford PS: Vasodilatory mechanisms in contracting skeletal muscle. J Appl Physiol (1985) 2004, 97:393-403

26. Baligand C, Jouvion G, Schakman O, Gilson H, Wary C, Thissen JP, Carlier PG: Multiparametric functional nuclear magnetic resonance imaging shows alterations associated with plasmid electrotransfer in mouse skeletal muscle. J Gene Med 2012, 14:598-608

27. Yemisci M, Gursoy-Ozdemir Y, Vural A, Can A, Topalkara K, Dalkara T: Pericyte contraction induced by oxidative-nitrative stress impairs capillary reflow despite successful opening of an occluded cerebral artery. Nat Med 2009, 15:1031-1037

28. Ito K: Smooth muscle-specific dystrophin expression improves aberrant vasoregulation in $\mathrm{mdx}$ mice. Hum $\mathrm{Mol}$ Genet 2006, 15: $2266-2275$

29. Loufrani L, Matrougui K, Gorny D, Duriez M, Blanc I, Levy BI, Henrion D: Flow (shear stress)-induced endothelium-dependent dilation is altered in mice lacking the gene encoding for dystrophin. Circulation 2001, 103:864-870

30. Brenman JE, Chao DS, Xia H, Aldape K, Bredt DS: Nitric oxide synthase complexed with dystrophin and absent from skeletal muscle sarcolemma in Duchenne muscular dystrophy. Cell 1995, 82:743-752

31. Sander M, Chavoshan B, Harris SA, Iannaccone ST, Stull JT, Thomas GD, Victor RG: Functional muscle ischemia in neuronal nitric oxide synthase-deficient skeletal muscle of children with Duchenne muscular dystrophy. Proc Natl Acad Sci U S A 2000, 97: $13818-13823$

32. Jiang C, Wen Y, Kuroda K, Hannon K, Rudnicki MA, Kuang S: Notch signaling deficiency underlies age-dependent depletion of satellite cells in muscular dystrophy. Dis Model Mech 2014, 7:997-1004

33. Fong GH, Rossant J, Gertsenstein M, Breitman ML: Role of the Flt-1 receptor tyrosine kinase in regulating the assembly of vascular endothelium. Nature 1995, 376:66-70

34. Verma M, Asakura Y, Hirai H, Watanabe S, Tastad C, Fong GH, Ema M, Call JA, Lowe DA, Asakura A: Flt-1 haploinsufficiency ameliorates muscular dystrophy phenotype by developmentally increased vasculature in $\mathrm{mdx}$ mice. Hum Mol Genet 2010, 19: 4145-4159

35. Deasy BM, Feduska JM, Payne TR, Li Y, Ambrosio F, Huard J: Effect of VEGF on the regenerative capacity of muscle stem cells in dystrophic skeletal muscle. Mol Ther 2009, 17:1788-1798

36. Messina S, Mazzeo A, Bitto A, Aguennouz M, Migliorato A, De Pasquale MG, Minutoli L, Altavilla D, Zentilin L, Giacca M, Squadrito F, Vita G: VEGF overexpression via adeno-associated virus gene transfer promotes skeletal muscle regeneration and enhances muscle function in mdx mice. FASEB J 2007, 21:3737-3746 
37. Trinity JD, Layec G, Lee JF: Heterogeneity of blood flow: impact of age on muscle specific tissue perfusion during exercise. J Physiol 2014, 592:1729-1730

38. Rudroff T, Weissman JA, Bucci M, Seppanen M, Kaskinoro K, Heinonen I, Kalliokoski KK: Positron emission tomography detects greater blood flow and less blood flow heterogeneity in the exercising skeletal muscles of old compared with young men during fatiguing contractions. J Physiol 2014, 592:337-349

39. Cole MA, Rafael JA, Taylor DJ, Lodi R, Davies KE, Styles P: A quantitative study of bioenergetics in skeletal muscle lacking utrophin and dystrophin. Neuromuscul Disord 2002, 12:247-257

40. Dunn JF, Frostick S, Brown G, Radda GK: Energy status of cells lacking dystrophin: an in vivo/in vitro study of $\mathrm{mdx}$ mouse skeletal muscle. Biochim Biophys Acta 1991, 1096:115-120

41. Heerschap A, Bergman AH, van Vaals JJ, Wirtz P, Loermans HM, Veerkamp JH: Alterations in relative phosphocreatine concentrations in preclinical mouse muscular dystrophy revealed by in vivo NMR. NMR Biomed 1988, 1:27-31

42. Dunn JF, Tracey I, Radda GK: Exercise metabolism in Duchenne muscular dystrophy: a biochemical and [31P]-nuclear magnetic resonance study of mdx mice. Proc Biol Sci 1993, 251:201-206

43. Kemp GJ, Taylor DJ, Dunn JF, Frostick SP, Radda GK: Cellular energetics of dystrophic muscle. J Neurol Sci 1993, 116: 201-206

44. Percival JM, Siegel MP, Knowels G, Marcinek DJ: Defects in mitochondrial localization and ATP synthesis in the mdx mouse model of Duchenne muscular dystrophy are not alleviated by PDE5 inhibition. Hum Mol Genet 2013, 22:153-167

45. Vidal GWC, Giacomini E, Emmanuel F, Carlier PG: A truly noninvasive set-up for the study of perfusion and energy metabolism in the rat calf in vivo: application to a model of peripheral arterial disease (Abstract). MAGMA 2002, 25:15 